\title{
PENGARUH MOTIVASI SISWA DALAM MENGIKUTI EKSTRAKURIKULER BOLA VOLI DI SMP NEGERI 13 KOTA BEKASI
}

\author{
Samsudin $^{1}$, Endang Sri Rejeki ${ }^{2}$, Bonaventura Purnama ${ }^{3}$ \\ ${ }^{1}$ Program Studi Pendidikan Jasmani, Fakultas Ilmu Olahraga, Universitas Negeri Jakarta Jl. Pemuda No. \\ 10 Rawamangun Jakarta Indonesia \\ samsudin@unj.ac.id, endangsrirejeki7@gmail.com
}

\begin{abstract}
Abstrak. Penelitian ini bertujuan untuk mengetahui motivasi siswa dalam mengikuti kegiatan ekstrakurikuler bola voli. Bagaimana motivasi dan apa yang menjadi motivasi siswa mengikuti ekstrakurikuler Bola Voli di SMP Negeri 13 Kota Bekasi. Apa tujuan siswa mengikuti ekstrakurikuler Bola Voli di SMP Negeri 13 Kota Bekasi. Penelitian ini merupakan penelitian kuantitatif dengan metode analisis deskriptif presentase, sedangkan metode pengumpulan data yang digunakan oleh peneliti adalah angket/kuesioner. Pengambilan sampel menggunakan teknik total sampling yaitu semua siswa yang mengikuti ekstrakurikuler Bola Voli di SMP Negeri 13 Kota Bekasi yang berjumlah 10 anak.

Hasil penelitian menunjukkan bahwa $67,9 \%$ responden memiliki motivasi yang tinggi. 26,6\% memiliki motivasi sedang. 5,5\% memiliki motivasi rendah, dan tidak ada responden yang memiliki motivasi sangat rendah terhadap ekstrakurikuler Bola Voli di SMP Negeri 13 Kota Bekasi. Motivasi siswa mengikuti ekstrakurikuler Bola Voli lebih dipengaruhi oleh motivasi instrinsik dengan hasil presentase 51,28\%, sedangkan untuk motivasi ekstrinsik hasil presentase $48,72 \%$. Tujuan siswa mengikuti ekstrakurikuler Bola Voli adalah agar bisa bermain Bola Voli, menambah pengalaman baru, mengembangkan bakat, ingin berprestasi, menambah teman dan mengisi waktu luang. Dari hasil penelitian maka dapat disimpulkan bahwa di SMP Negeri 13 Kota Bekasi Jepara memiliki motivasi yang tinggi terhadap ekstrakurikuler Bola Voli, yaitu 67,9\% responden. Saran kepada Pihak Sekolah diharapkan pihak sekolah ikut dalam usaha peningkatan prestasi siswa dengan cara memperhatikan sarana dan prasarana yang tersedia. Kepada pelatih diharapkan berusaha untuk menumbuhkan motivasi intrinsik dalam diri siswa, karena siswa yang termotivasi secara intrinsik akan menunjukkan keterlibatan dan aktifitas yang tinggi dalam berlatih Bola Voli.
\end{abstract}

Kata kunci: Motivasi, Ekstrakurikuler, Bola Voli.

\section{PENDAHULUAN}

kegiatan ekstrakurikuler adalah kegiatan di luar jam pelajaran untuk membantu pengembangan peserta didik sesuai dengan kebutuhan, potensi, bakat, dan minat mereka melalui kegiatan yang secara khusus diselenggarakan oleh pendidik dan atau tenaga kependidikan yang 
berkemampuan dan berkewenangan di sekolah/madrasah. Hal ini sangat dibutuhkan oleh siswa karena pada umur seperti mereka saat ini, siswasiswi SMP memiliki energi berlebih yang ada dalam tubuh mereka yang sebaiknya harus disalurkan ke suatu kegiatan positif yang dapat membuat mereka mengerahkan seluruh energi mereka ke dalam kegiatan tersebut. Saat berada di lingkungan sekolah, tempat yang tepat adalah kegiatan ekstrakurikuler, karena di sana siswa dapat menyalurkan energi ke ekstrakurikuler yang mereka gemari.

Kegiatan ekstrakurikuler sebagai bagian dari kebijaksanaan pendidikan secara menyeluruh yang mempunyai tugas pokok sebagai berikut: 1) Memperdalam dan memperluas pengetahuan siswa, dalam arti memperkaya, mempertajam, serta memperbaiki pengetahuan para siswa yang berkaitan dengan mata pelajaran sesuai dengan program kurikulum yang ada. 2) Mengenal hubungan antara berbagai mata pelajaran. 3) Menyalurkan serta membina bakat, minat, keterampilan, dan hasil yang diharapkan ialah untuk memacu anak ke arah kemampuan mandiri, percaya diri, dan kreatif. 4) Melengkapi upaya pembinaan manusia seutuhnya.

Berdasarkan uraian di atas, dapat disimpulkan bahwa kegiatan ekstrakurikuler di sekolah mempunyai tugas yang mulia. Kegiatan ekstrakurikuler dapat dijadikan wadah untuk menampung minat dan bakat siswa-siswi, bahkan sampai meraih prestasi tinggi sesuai dengan bidang kegiatan ekstrakurikuler yang diminatinya. Latihan yang rutin diperlukan untuk meningkatkan bakat yang sudah dimiliki.
Secara garis besar, ekstrakurikuler di sekolah terbagi menjadi dua bagian, yaitu: ekstrakurikuler olahraga dan ekstrakurikuler bukan olahraga. Yang termasuk dalam ekstrakurikuler olahraga ialah: olahraga permainan (sepakbola, basket, futsal, voli, dan bulutangkis), ektrakurikuler olahraga atletik (lari, lempar, dan lompat), ekstrakurikuler olahraga akuatik (renang), dan ekstrakurikuler olahraga beladiri (karate, pencak silat, taekwondo). Sedangkan ekstrakurikuler bukan olahraga ialah: ekstrakurikuler musik (band, marching band, paduan suara), ekstrakurikuler tari (tari tradisional, modern dance, dan cheerleader), ekstrakurikuler teater, ekstrakurikuler karya ilmiah, ekstrakurikuler pramuka, ekstrakurikuler pecinta alam, dan paskibraka.

Keikutsertaan siswa dalam kegiatan luar akademik seperti ekstrakurikuler ini memiliki banyak dampak positif bagi siswa: 1) Siswa mampu mengembangkan kemampuan dan kreativitas sesuai potensi, bakat, dan minat mereka, 2) Mampu mengembangkan kemampuan berinteraksi sosial terhadap siswa lain, 3) Mampu menimbulkan suasana rileks, meng-gembirakan, dan menyenangkan bagi siswa yang sudah disibukkan dengan proses pembelajaran akademik.

Sardiman mengatakan motivasi adalah perubahan energi dalam diri seseorang yang ditandai dengan munculnya "feeling" dan didahului dengan tanggapan terhadap adanya tujuan. Oleh karena itu motivasi berpengaruh terhadap kegiatan ekstrakurikuler dalam rangka mencapai tujuan pendidikan, yaitu meningkatkan kualitas sumber daya manusia, antara lain: aktivitas belajar-mengajar formal, dan berbagai kegiatan-kegiatan yang menunjang pengembangan bakat dan 
minat para siswa. Ekstrakurikuler ditujukan pula sebagai hal positif untuk menunjang kemampuan siswa. Dari sejumlah ahli yang merumuskan klasifikasi motivasi, pembagian yang paling populer membagi motivasi menjadi dua bentuk yaitu motivasi instrinsik dan motivasi ekstrinsik. Motivasi instrinsik terjadi bila motivasi tersebut bersumber dari dalam diri sendiri. Sementara motivasi ekstrinsik terjadi bila dorongan bertindak datang dari luar diri. Motivasi dapat juga dikatakan serangkaian usaha untuk menyediakan kondisi-kondisi tertentu, sehingga seseorang mau dan ingin melakukan sesuatu, dan bila ia tidak suka, maka akan berusaha untuk meniadakan atau mengelakkan perasaan tidak suka itu. Jadi motivasi itu dapat dirangsang oleh faktor dari luar tetapi motivasi itu adalah tumbuh di dalam diri seseorang.

Hal positif yang dapat diperoleh siswa dari ekstrakurikuler ini seharusnya dapat dijadikan pertimbangan yang serius bagi semua sekolah jika mengadakan kegiatan ekstrakurikuler di sekolahnya. Bahkan dapat dijadikan sebagai media siswa untuk meraih prestasi di bidang non akademik. Masalah yang sering muncul adalah terhentinya semangat dan minat siswa terhadap ekstrakurikuler, beberapa alasannya adalah tidak tersedianya waktu untuk belajar dan istirahat, lingkungan/ keluarga yang tidak mendukung, tidak percaya diri, dan merasa tidak mampu.

Lenk (1983) yang dikutip oleh Lutan (1992:14) mengatakan bahwa, "Dorongan berprestasi atau mencapai hasil yang lebih baik merupakan ciri hakiki pada manusia. Karena itulah, manusia dapat bertahan dan terus kian maju melalui proses aktif dalam membentuk dirinya dan dunia sekitarnya." Dengan demikian, maka dalam pencapaian suatu prestasi, potensi diri dan pengembangan diri dalam suatu aktivitas tertentu merupakan faktor-faktor yang menentukan tingkat pencapaian suatu prestasi. Ada banyak faktor yang bekerja dibalik prestasi olahraga, jika digolongkan maka terdapat dua faktor secara garis besar yakni faktor endogen (dalam diri) dan faktor eksogen (lingkungan). 1. Faktor endogen dalam diri seorang atlet mencakup unsur fisik dan unsur psikis atau mental. Unsur fisik terkait pada ukuran tubuh, kesehatan tubuh, kapasitas paru, kecepatan, kekuatan otot, daya tahan, fleksibilitas, ketangkasan dan keseimbangan. Unsur mental atau psikis berkaitan dengan kesehatan mental, keberanian, motivasi dan keinginan untuk menang. 2. Faktor eksogen mencakup latihan fisik dan teknik terhadap atlet, sarana dan prasarana, kondisi lingkungan, gaji dan penghargaan. Latihan yang diterima oleh atlet sangat berpengaruh terhadap kualitasnya dalam bertandingan. Sementara itu, latihan berkaitan dengan sarana dan prasarana olahraga yang dimiliki dan digunakan oleh atlet dalam berlatih.

Proses pembinaan atlet bagi suatu cabang olahraga perlu memperhatikan kondisi dari faktor endogen dan eksogen atlet. Seperti dikemukakan di atas bahwa faktor eksogen adalah semua hal di luar diri individu, maka bagi seorang atlet faktor eksogen ini dapat berupa latihan-latihan, sarana dan prasarana latihan, keadaan lingkungan, penghargaan dan lain sebagainya. Dalam proses pembinaan atlet hendaknya fungsi faktor eksogen harus benar-benar optimal, artinya kondisi 
dari pelatihan yang ada dapat memberikan kontribusi yang positif dan menunjang terhadap pencapaian tujuan.

Latihan merupakan salah satu faktor eksogen yang berpengaruh langsung terhadap prestasi yang dicapai oleh atlet, karena itu latihan-latihan yang dilakukan harus mencakup segala aspek yang dibutuhkan oleh tuntutan dari olahraganya. Pengoptimalan fungsi faktor eksogen dalam pengembangan faktor endogen atlet adalah hal utama bagi usaha peningkatan dan pencapaian suatu prestasi. Jumlah latihan pada SMP Negeri 13 Kota Bekasi dalam seminggu rata-rata 2-3 dalam seminggu, hal ini menunjukkan bahwa latihan ekstrakurikuler belum optimal dan menjadi salah satu penghambat peningkatan prestasi ekstrakurikuler Bola Voli.

Pada umumnya kendala yang sering dihadapi dalam kegiatan ekstrakurikuler adalah cuaca yang buruk seperti hujan dan kurangnya antusias dari peserta ekstra-kurikuler sehingga materi yang disampaikan tidak maksimal. Hasil observasi menunjukkan jarak yang jauh antara rumah siswa dan sekolah menyebabkan kurangnya minat siswa terhadap ekstrakurikuler Bola Voli, hal itu menjadi kendala yang menghambat kegiatan ekstrakurikuler di SMP Negeri 13 Kota Bekasi.

Adanya ekstrakurikuler Bola Voli di Sekolah seharusnya bisa mendongkrak prestasi olahraga salah satunya pada Pekan Olahraga Pelajar Daerah (POPDA). Namun dalam kenyataannya, ekstrakurikuler Bola Voli di SMP Negeri 13 Kota Bekasi masih belum ada yang berprestasi ditingkat POPDA.

Berdasarkan latar belakang tersebut penulis tertarik untuk melakukan penelitian tentang Motivasi siswa terhadap ekstrakurikuler Bola Voli di SMP Negeri 13 Kota Bekasi dengan judul "Survei Motivasi Siswa dalam Kegiatan Ekstrakurikuler Bola Voli di SMP Negeri 13 Kota Bekasi Tahun 2019"

Motivasi tidak dapat dipisahkan dari kebutuhan seseorang sebagai organisme yang hidup dalam melakukan suatu perbuatan. Motivasi adalah sesuatu daya yang menjadi pendorong seseorang bertindak, dimana rumusan motivasi menjadi sebuah kebutuhan nyata dan merupakan muara dari sebuah tindakan (Akyas azhari, 2004: 65). Berasal dari kata motif yang dapat diartikan sebagai upaya yang mendorong seseorang untuk melakukan sesuatu. Motif dapat dikatakan sebagai daya penggerak dari dalam dan didalam seseorang untuk melakukan aktivitas-aktivitas tertentu demi mencapai suatu tujuan (Sadirman, 2006: 73).

Motivasi dapat juga dikatakan serangkaian usaha untuk menyediakan kondisi-kondisi tertentu, sehingga seseorang mau dan ingin melakukan sesuatu, dan bila ia tidak suka, maka akan berusaha untuk meniadakan atau mengelakkan perasaan tidak suka itu. Jadi motivasi itu dapat dirangsang oleh faktor dari luar tetapi motivasi itu adalah tumbuh di dalam diri seseorang. Motivasi belajar adalah merupakan faktor psikis yang bersifat nonintelektual. Motivasi menurut Achmad Rifa merupakan salah satu faktor yang ikut menentukan keberhasilan anak dalam proses belajar (Achmad Rifa, 2012: 133).

Motivasi adalah suatu perubahan energi dari pribadi seseorang yang di tandai dengan timbulnya afektif dan reaksi untuk mencapai tujuan. Rumusan 
ini memiliki unsur bahwa motivasi dimulai dari adanya perubahan energy dalam pribadi, motivasi di mulai dari timbulnya perasaan (afektif) dan motivasi di tandai oleh reaksi-reaksi untuk mencapai tujuan. Menurut Slavin sebagaimana telah dikutip A. Rifa'i dan Catharina Tri Anni Motivasi merupakan proses internal yang mengaktifkan, memandu, dan memelihara perilaku seseorang secara terus-menerus (A. Rifa'i dan Catharina Tri Anni 2011: 159160). Dalam pengertian ini intensitas dan arah motivasi dapat bervariasi. Motivasi untuk melakukan sesuatu berasal dari berbagai faktor seperti karakteristik kepribadian. Individu mungkin memilki minat yang cukup dan mantap dalam berpartisipasi pada berbagai kegiatan seperti akademik, olah raga dan aktivitas sosial.

Abraham Maslow mengemukakan bahwa pada dasarnya semua manusia memiliki kebutuhan pokok. Ia menunjukkannya dalam 5 tingkatan yang berbentuk piramid, orang memulai dorongan dari tingkatan terbawah (Abraham Maslow: 1943;1970). Lima tingkat kebutuhan itu dikenal dengan sebutan Hirarki Kebutuhan Maslow, dimulai dari kebutuhan biologis dasar sampai motif psikologis yang lebih kompleks; yang hanya akan penting setelah kebutuhan dasar terpenuhi. Kebutuhan pada suatu peringkat paling tidak harus terpenuhi sebagian sebelum kebutuhan pada peringkat berikutnya menjadi penentu tindakan yang penting.

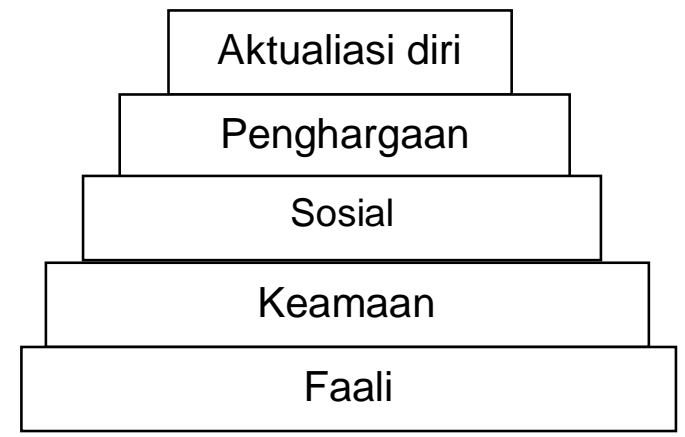

- Kebutuhan fisiologis (rasa lapar, rasa haus, dan sebagainya)

- Kebutuhan rasa aman (merasa aman dan terlindung, jauh dari bahaya)

- Kebutuhan akan rasa cinta dan rasa memiliki (berafiliasi dengan orang lain, diterima, memiliki)

- Kebutuhan akan penghargaan (berprestasi, berkompetensi, dan mendapatkan dukungan serta pengakuan)

- Kebutuhan aktualisasi diri (kebutuhan kognitif: mengetahui, memahami, dan menjelajahi; kebutuhan estetik: keserasian, keteraturan, dan keindahan; kebutuhan aktualisasi diri: mendapatkan kepuasan diri dan menyadari potensinya)

Bila makanan dan rasa aman sulit diperoleh, pemenuhan kebutuhan tersebut akan mendominasi tindakan seseorang dan motif-motif yang lebih tinggi akan menjadi kurang signifikan. Orang hanya akan mempunyai waktu dan energi untuk menekuni minat estetika dan intelektual, jika kebutuhan dasarnya sudah dapat dipenuhi dengan mudah. Karya seni dan karya ilmiah tidak akan tumbuh subur dalam masyarakat yang anggotanya masih harus bersusah payah mencari makan, perlindungan, dan rasa aman.

Dari McClelland dikenal tentang teori kebutuhan untuk mencapai prestasi atau Need for Acievement (N.Ach) yang menyatakan bahwa motivasi berbedabeda, sesuai dengan kekuatan kebutuhan seseorang akan prestasi. Murray sebagaimana dikutip oleh Winardi merumuskan kebutuhan akan prestasi tersebut sebagai keinginan: "Melaksanakan sesuatu tugas atau pekerjaan yang sulit. Menguasai, 
memanipulasi, atau mengorganisasi obyek-obyek fisik, manusia, atau ide-ide melaksanakan hal-hal tersebut secepat mungkin dan seindependen mungkin, sesuai kondisi yang berlaku. Mengatasi kendala-kendala, mencapai standar tinggi. Mencapai performa puncak untuk diri sendiri. Mampu menang dalam persaingan dengan pihak lain. Meningkatkan kemampuan diri melalui penerapan bakat secara berhasil."

Teori Alderfer dikenal dengan akronim "ERG". Akronim "ERG" dalam teori Alderfer merupakan huruf-huruf pertama dari tiga istilah yaitu: $\mathrm{E}=$ Existence (kebutuhan akan eksistensi), $\mathrm{R}$ $=$ Relatedness (kebutuhan untuk berhubungan dengan pihak lain, dan $\mathrm{G}=$ Growth (kebutuhan akan pertumbuhan).

Jika makna tiga istilah tersebut didalami akan tampak dua hal penting. Pertama, secara konseptual terdapat persamaan antara teori atau model yang dikembangkan oleh Maslow dan Alderfer. Karena "Existence" dapat dikatakan identik dengan hierarki pertama dan kedua dalam teori Maslow; "Relatedness" senada dengan hierarki kebutuhan ketiga dan keempat menurut konsep Maslow dan "Growth" mengandung makna sama dengan "self actualization" menurut Maslow. Kedua, teori Alderfer menekankan bahwa berbagai jenis kebutuhan manusia itu diusahakan pemuasannya secara serentak. Apabila teori Alderfer disimak lebih lanjut akan tampak bahwa:

- Makin tidak terpenuhinya suatu kebutuhan tertentu, makin besar pula keinginan untuk memuaskannya;

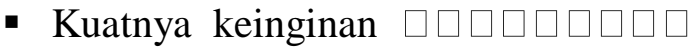
kebutuhan yang "lebih tinggi" semakin besar apabila kebutuhan yang lebih rendah telah dipuaskan.
Sebaliknya, semakin sulit memuaskan kebutuhan yang tingkatnya lebih tinggi, semakin besar keinginan untuk memuaskan kebutuhan yang lebih mendasar. Pandangan ini didasarkan kepada sifat pragmatisme oleh manusia. Artinya, karena menyadari keterbatasannya, seseorang dapat menyesuaikan diri pada kondisi obyektif yang dihadapinya dengan antara lain memusatkan perhatiannya kepada hal-hal yang mungkin dicapainya.

Ilmuan ketiga yang diakui telah memberikan kontribusi penting dalam pemahaman motivasi Herzberg. Teori yang dikembangkannya dikenal dengan "Model Dua Faktor" dari motivasi, yaitu faktor motivasional dan faktor hygiene atau "pemeliharaan". Menurut teori ini yang dimaksud faktor motivasional adalah hal-hal yang mendorong berprestasi yang sifatnya intrinsik, yang berarti bersumber dalam diri seseorang, sedangkan yang dimaksud dengan faktor hygiene atau pemeliharaan adalah faktor-faktor yang sifatnya ekstrinsik yang berarti bersumber dari luar diri yang turut menentukan perilaku seseorang dalam kehidupan seseorang.

Menurut Herzberg, yang tergolong sebagai faktor motivasional ialah pekerjaan seseorang, keberhasilan yang diraih, kesempatan bertumbuh, kemajuan dalam karier dan pengakuan orang lain. Sedangkan faktor-faktor hygiene atau pemeliharaan mencakup antara lain status seseorang dalam organisasi, hubungan seorang individu dengan atasannya, hubungan seseorang dengan rekan-rekan sekerjanya, teknik penyeliaan yang diterapkan oleh para penyelia, kebijakan organisasi, sistem administrasi dalam organisasi, kondisi 
kerja dan sistem imbalan yang berlaku. Salah satu tantangan dalam memahami dan menerapkan teori Herzberg ialah memperhitungkan dengan tepat faktor mana yang lebih berpegaruh kuat dalam kehidupan seseorang, apakah yang bersifat intrinsik ataukah yang bersifat ekstrinsik.

Victor H. Vroom, dalam bukunya yang berjudul "Work And Motivation" mengetengahkan suatu teori yang disebutnya sebagai "Teori Harapan". Menurut teori ini, motivasi merupakan akibat suatu hasil dari yang ingin dicapai oleh seorang dan perkiraan yang bersangkutan bahwa tindakannya akan mengarah kepada hasil yang diinginkannya itu. Artinya, apabila seseorang sangat menginginkan sesuatu, dan jalan tampaknya terbuka untuk memperolehnya, yang bersangkutan akan berupaya mendapatkannya.

\section{Macam-Macam Motivasi}

Macam-macam motivasi akan dibahas dari dua sudut pandang, yakni motivasi yang berasal dari dalam diri pribadi seseorang yang disebut "motivasi instrinsik" dan motivasi yang berasal dari luar diri seseorang yang disebut "motivasi ekstrinsik" (Djamarah S.B., 2008: 149-152)

Motivasi Instrinsik adalah motifmotif yang menjadi aktif atau berfungsinya tidak perlu dirangsang dari luar, karena dalam setiap diri individu sudah ada dorongan untuk melakukan sesuatu. Dorongan untuk belajar bersumber pada kebutuhan yang berisikan keharusan untuk menjadi orang yang terdidik dan berpengetahuan. Jadi motivasi instrinsik muncul berdasarkan kesadaran dengan tujuan esensial, bukan sekedar atribut atau seremonial.

\begin{abstract}
Motivasi ekstrinsik adalah kebalikan dari motivasi instrinsik. Motivasi ekstrinsik adalah motif-motif yang aktif dan berfungsi karena adanya perangsang dari luar.
\end{abstract}

Faktor yang Mempengaruhi Prestasi

Menurut Lenk yang dikutip oleh Lutan dikatakan bahwa, "Dorongan berprestasi atau mencapai hasil yang lebih baik merupakan ciri hakiki pada manusia (Lenk (1983) yang dikutip oleh Lutan, 1992: 14). Karena itulah, manusia dapat bertahan dan terus kian maju melalui proses aktif dalam membentuk dirinya dan dunia sekitarnya." Dengan demikian, maka dalam pencapaian suatu prestasi, potensi diri dan pengembangan diri dalam suatu aktivitas tertentu merupakan faktor-faktor yang menentukan tingkat pencapaian suatu prestasi. Tentang hal ini, Lutan menjelaskan sebagai berikut:

\section{Tujuan Motivasi}

Secara umum dapat dikatakan bahwa tujuan motivasi adalah untuk menggerakkan atau menggugah seseorang agar timbul keinginan dan kemauannya untuk melakukan sesuatu sehingga dapat memperoleh hasil atau mencapai tujuan tertentu.

Ekstrakurikuler

Ekstrakurikuler merupakan kegiatan yang sekolah adakan untuk mewadahi semua bakat dan minat yang dimiliki masing-masing siswa. Definisi ekstra-kurikuler menurut beberapa sumber antara lain:

Ekstrakurikuler adalah kegiatan di luar jam pelajaran sekolah yang dilakukan baik di sekolah maupun di luar sekolah dengan tujuan untuk 
memperdalam dan memperluas pengetahuan siswa, mengenal hubungan antar berbagai pelajar, menyalurkan bakat dan minat serta melengkapi dalam upaya pembinaan manusia seutuhnya.

Kegiatan ekstrakurikuler di sekolah ikut andil dalam meningkatkan kecerdasan peserta didik. Kegiatan ini bukan termasuk materi pelajaran yang terpisah dari materi pelajaran lainnya, bahwa dapat dilaksanakan disela-sela mata pelajaran, mengingat kegiatan tersebut merupakan bagian penting dari kurikulum sekolah (Amal, 2005: 378).

Kegiatan ekstrakurikuler adalah kegiatan di luar mata pelajaran untuk membantu pengembangan peserta didik sesuai dengan kebutuhan, potensi, bakat, dan minat mereka melalui kegiatan yang secara khusus diselenggarakan oleh pendidik dan atau tenaga kependidikan yang berkemampuan dan berkewenangan di sekolah/madrasah (Anifral Hendri, 2008: 1-2).

Menurut Ahmadi (dalam Ade Yuliasari dan Nanang Indriarsa) kegiatan ekstrakurikuler adalah kegiatan-kegiatan di luar jam pelajaran sekolah yang mempunyai fungsi pendidikan dan biasanya berupa klub-klub, misalnya: olahraga, kesenian, ekspresi dan lain-lain (Ade Yuliasari dan Nanang Indriarsa, 2013: 316).

c. Tujuan Ekstrakurikuler

Dalam setiap kegiatan yang dilakukan, pasti tidak lepas dari aspek tujuan. Kerena suatu kegiatan yang diakukan tanpa jelas tujuannya, maka kegiatan itu akan sia-sia. Begitu pula dengan kegiatan ekstrakurikuler tertentu memiliki tujuan tertentu. Mengenai tujuan kegiatan dalam ekstrakurikuler dijelasken oleh Departemen Pendidikan dan Kebudayaan (1995:2) sebagai berikut:

1. Siswa dapat memperdalam dan memperluas pengetahuan keterampilan mengenai hubungan antara berbagai mata pelajaran, menyalurkan

bakat dan minat, serta melengkapi upaya pembinaan manusia seutuhnya yang;

a. Beriman dan bertaqwa kepada Tuhan Yang Maha Esa

b. Berbudi pekerti luhur

c. Memiliki pengetahuan keterampilan

d. Sehat rohani dan jasmani

e. Berkepribadian yang mantap dan mandiri

f. Memiliki rasa tanggung jawab kemasyarakatan dan kebangsaan

2. Siswa mampu memanfaatkan pendidikan kepribadian serta mengaitkan pengetahuan yang diperoleh dalam program kurikulum dengan kebutuhan dan keadaan lingkungan.

Dari penjelasan di atas pada hakekatnya tujuan kegiatan ekstrakurikuler yang ingin dicapai adalah untuk kepentingan siswa. Dengan kata lain kegiatan ekstrakurikuler memiliki nilai-nilai pendidikan bagi siswa dalam upaya pembinaan manusia seutuhnya.

Bola Voli

Menurut Samsudin permainan bola voli adalah suatu permainan yang menggunakan bola besar dengan dipantulkan dengan satu tangan atau dua tangan dengan melewati net, dimainkan oleh dua regu putra atau putri. Tiap regu berusaha untuk membuat angka sebanyak-banyaknya dengan mematikan bola di daerah lawan (Samsudin, 2018).

Bola voli termasuk permainan yang kompleks, artinya gerakan terdiri 
dari gabungan unsur-unsur gerak yang terkoordinasi rapi sehingga dapat dimainkan dengan baik.

Adapun dalam memainkan bola voli dikenal teknik dasar yang meliputi servis atas, servis bawah, pasing atas, pasing bawah, dan smash serta block. Permainan bola voli dimainkan di sekolah-sekolah, baik sekolah dasar, sekolah menengah pertama, dan sekolah menengah atas serta perguruan tinggi.

\section{METODE}

Metode

penelitian

ini menggunakan metode deskriptif dengan survey pengaruh, dengan teknik pengumpulan data yaitu angket. Pada penelitian ini terdapat 2 (dua) variabel, yaitu motivasi intrinsik dan ekstrinsik.

\section{HASIL DAN PEMBAHASAN}

Analisis motivasi siswa berikut bertujuan untuk mengetahui besarnya motivasi siswa terhadap ekstrakurikuler Bola Voli di SMP Negeri 13 Kota Bekasi. Secara umum pengukuran motivasi siswa berdasarkan dari jumlah skor yang dijawab setiap responden dalam pengisian angket atau kuisioner. Hasilnya adalah sebagai berikut:

Tabel 1. Deskripsi Motivasi Siswa

\begin{tabular}{cccccc}
\hline & \multicolumn{2}{c}{ Interval } & \multicolumn{2}{c}{ Keterangan Jumlah } & $\%$ \\
\hline 1 & $81,25 \%$ & $-100 \%$ & Tinggi & 679 & $67,9 \%$ \\
\hline 2 & $62,50 \%$ & $-81,25 \%$ & Sedang & 266 & $26,6 \%$ \\
\hline 3 & $43,75 \%$ & $-62,50 \%$ & Rendah & 55 & $5,5 \%$ \\
\hline 4 & $25,00 \%$ & $-43,75 \%$ & $\begin{array}{c}\text { Rendah } \\
\text { sekali }\end{array}$ & 0 & $0 \%$
\end{tabular}

Tabel 1 di atas menunjukkan bahwa secara garis besar motivasi siswa terhadap ekstrakurikuler Bola Voli di SMP Negeri 13 Kota Bekasi dikategorikan pada tingkatan yang tinggi dengan presentase sebesar $67,5 \% \%$.

Motivasi Siswa

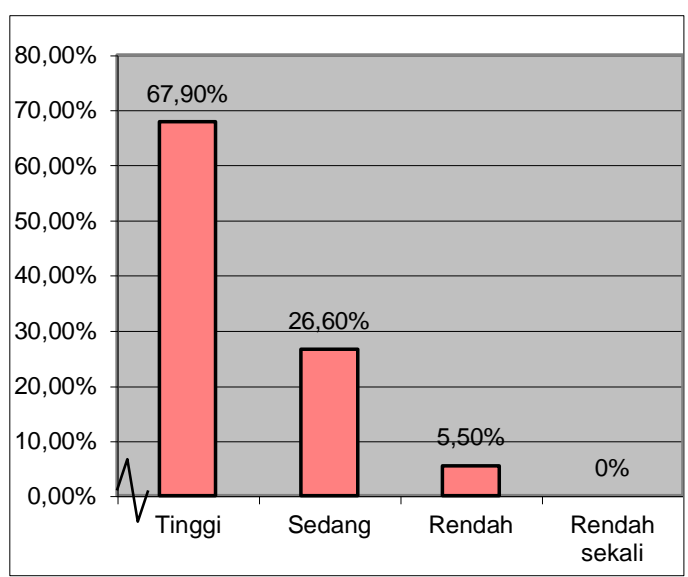

Gambar 1. Distribusi Frekuensi Motivasi Siswa Terhadap Ekstrakurikuler Bola Voli di SMP Negeri 13 Kota Bekasi.

Sebagian besar siswa di SMP Negeri 13 Kota Bekasi memiliki motivasi terhadap ekstrakurikuler Bola Voli pada kategori tingkat yang tinggi yaitu $62 \%$, dimana kondisi ini berada pada inetrval $81,25 \%-100 \%$.

Tabel 2. Skor Hasil Pengisian Kuesioner

\begin{tabular}{cccc} 
No. & Indikator & $\begin{array}{c}\text { Skor } \\
\text { Jumlah }\end{array}$ & Presentase(\%) \\
\hline 1 & Pengalaman & 111 & $12,29 \%$ \\
\hline 2 & Fisiologis & 104 & $11,52 \%$ \\
\hline 3 & Aktualisasi diri & 100 & $11,07 \%$ \\
\hline 4 & Rasa & 130 & $14,40 \%$ \\
\hline 5 & Perhatian & 125 & $13,84 \%$ \\
\hline 6 & Perasaan & 128 & $14,17 \%$ \\
\hline 7 & Kepercayaan diri & 114 & $12,62 \%$ \\
\hline 8 & Penghargaan & 91 & $10,08 \%$ \\
\hline & Jumlah & 903 & $100 \%$
\end{tabular}


Tabel 3. Skor Hasil Pengisian Motivasi Instrinsik

\begin{tabular}{ccccc} 
No & $\begin{array}{c}\text { Motivasi } \\
\text { Intrinsik }\end{array}$ & Nomor Soal & $\begin{array}{c}\text { Skor } \\
\text { Jumlah }\end{array}$ & $\%$ \\
\hline 1 & Pengalaman & 1,2 & 56 & $11.22 \%$ \\
\hline 2 & Fisiologis & $5,6,7,8$ & 116 & $23,25 \%$ \\
\hline 3 & Aktualisasi diri & 11 & 26 & $5,21 \%$ \\
\hline 4 & Rasa & 15,17 & 56 & $11,22 \%$ \\
\hline 5 & Perhatian & 21,23 & 58 & $11,62 \%$ \\
\hline 6 & Perasaan & $25,26,27,28$ & 99 & $19,84 \%$ \\
\hline 7 & Kepercayaan diri & $29,30,32,33$ & 88 & $17,64 \%$ \\
\hline 8 & Penghargaan & - & - & 0 \\
\hline & Jumlah & 19 & 499 & $100 \%$
\end{tabular}

Tabel 4. Skor Hasil Pengisian Motivasi Ekstrinsiknsik

\begin{tabular}{llccc} 
No. & $\begin{array}{c}\text { Motivasi } \\
\text { Ekstrinsik }\end{array}$ & Nomor Soal & $\begin{array}{c}\text { Skor } \\
\text { Jumlah }\end{array}$ & $\begin{array}{c}\text { Presentase } \\
(\%)\end{array}$ \\
\hline 1 & Pengalaman & 3,4 & 55 & $11, \%$ \\
\hline 2 & Fisiologis & - & 58 & $12,24 \%$ \\
\hline 3 & Aktualisasi diri & $9,10,12,13$ & 74 & $15,61 \%$ \\
\hline 4 & Rasa & $14,16,18$ & 74 & $15,61 \%$ \\
\hline 5 & Perhatian & $19,20,22$ & 67 & $14,14 \%$ \\
\hline 6 & Perasaan & 24 & 29 & $6,11 \%$ \\
\hline 7 & Kepercayaan diri & 31 & 26 & $5,48 \%$ \\
\hline & J & $34,35,36,37$, & 91 & $19,2 \%$ \\
\hline 8 & Penghargaan & 38 & & \\
\hline & Jumlah & 19 & 474 & $100 \%$
\end{tabular}

Hasil perhitungan presentase dari motivasi instrinsik dan motivasi ekstrinsik secara keseluruhan ialah:

\section{Tabel 5. Skor Total Motivasi Instrinsik dan Ekstrinsik}

\begin{tabular}{cccc} 
No & Motivasi & Skor total & Presentase \\
\hline 1 & Motivasi Instrinsik & 499 & $51,28 \%$ \\
\hline 2 & Motivasi Ekstrinsik & 474 & $48,72 \%$ \\
\hline & Jumlah & 973 & $100 \%$
\end{tabular}

Motivasi siswa mengikuti ekstra kurikuler Bola Voli

Hasil dari delapan indikator yang terdiri dari 38 soal instrumen dibagi menjadi 2 yaitu: motivasi instrinsik dan motivasi ekstrinsik, menunjukkan bahwa motivasi instrinsik lebih besar dari pada motivasi ekstrinsik yaitu dengan hasil sebagai $51,28 \%$. Jadi motivasi siswa mengikuti ekstrakurikuler Bola Voli sebagian besar dipengaruhi oleh motivasi instrinsik, yaitu motivasi dari dalam diri.

\section{PEMBAHASAN}

Motivasi siswa terhadap ekstrakurikuler Bola Voli di SMP Negeri 13 Kota Bekasi menunjukkan hasil bahwa dari 10 responden $67,9 \%$ diantaranya memiliki motivasi yang tinggi, sedangkan $26,6 \%$ lainnya memiliki motivasi yang sedang. Dan 5,5\% responden memiliki motivasi yang rendah.

Hasil dari delapan indikator yang terdiri dari 38 soal instrumen dibagi menjadi 2 yaitu: motivasi instrinsik dan motivasi ekstrinsik, menunjukkan bahwa motivasi instrinsik lebih besar dari pada motivasi ekstrinsik yaitu dengan hasil $51,28 \%$. Yang paling berpengaruh terhadap motivasi siswa mengikuti ekstrakurikuler Bola Voli ialah motivasi instrinsik, yaitu motivasi dari dalam diri. Motivasi instrinsik terjadi bila motivasi tersebut bersumber dari dalam diri sendiri. Sementara motivasi ekstrinsik terjadi bila dorongan bertindak datang dari luar diri. (Husdarta, 2010:40).

Ada banyak faktor yang bekerja dibalik prestasi olahraga, jika digolongkan maka terdapat dua faktor secara garis besar yakni faktor endogen (dalam diri) dan faktor eksogen (lingkungan). 1. Faktor endogen dalam diri seorang atlet mencakup unsur fisik dan unsur psikis atau mental. Unsur fisik terkait pada ukuran tubuh, 
kesehatan tubuh, kapasitas paru, kecepatan, kekuatan otot, daya tahan, fleksibilitas, ketangkasan dan keseimbangan. Unsur mental atau psikis berkaitan dengan kesehatan mental, keberanian, motivasi dan keinginan untuk menang. 2. Faktor eksogen mencakup latihan fisik dan teknik terhadap atlet, sarana dan prasarana, kondisi lingkungan, gaji dan penghargaan. Latihan yang diterima oleh atlet sangat berpengaruh terhadap kualitasnya dalam bertandingan. Sementara itu, latihan berkaitan dengan sarana dan prasarana olahraga yang dimiliki dan digunakan oleh atlet dalam berlatih. (Lutan, 1992:14)

Hal ini menunjukkan bahwa yang berperan dalam peningkatan prestasi bukan hanya motivasi siswa, karna ada banyak faktor yang mempengaruhi prestasi olahraga. Maka meskipun motivasi siswa mengikuti ekstrakurikuler Bola Voli di SMP Negeri 13 Kota Bekasi Tahun 2019 tinggi prestasinya belum tentu tinggi. Motivasi hanya salah satu unsur mental dari beberapa unsur pada faktor endogen, agar dapat berprestasi kedua faktor yaitu faktor endogen dan faktor eksogen harus diperhatikan.

Motivasi ekstrinsik berupa dukungan orang tua berperan serta dalam pelaksanaan ekstrakurikuler, beberapa hal yang menjadi tujuan siswa mengikuti ekstrakurikuler Bola Voli ialah agar bisa bermain Bola Voli, menambah pengalaman baru, mengembangkan bakat, ingin berprestasi, menambah teman dan mengisi waktu luang. Siswa dapat mengembangkan diri pada ekstrakurikuler Bola Voli, banyak manfaat yang dapat diraih selain tubuh yang sehat. Misalnya: berbagi pengalaman dengan teman yang lebih baik prestasinya akan menambah wawasan dan pengetahuan siswa terhadap dunia olahraga.

Peran Pihak sekolah juga memberikan sumbangsih terhadap motivasi siswa terhadap ekstrakurikuler Bola Voli di SMP Negeri 13 Kota Bekasi. Adapun indikator penilaiannya adalah perhatian dari guru dan penghargaan berupa nilai tambahan untuk mata pelajaran penjas. Untuk lebih maksimal apabila pihak sekolah memperbaiki sarana dan prasarana yang belum memenuhi standar.

\section{KESIMPULAN}

Berdasarkan hasil penelitiaan diatas dapat disimpulkan bahwa:

1. Motivasi Instrinsik dapat mempengaruhi motivasi siswa dalam mengikuti ekstrakurikuler Bola Voli di SMP Negeri 13 Kota Bekasi.

2. Motivasi ekstrinsik dapat mempengaruhi motivasi siswa dalam mengikuti ekstrakurikuler Bola Voli di SMP Negeri 13 Kota Bekasi.

\section{DAFTAR PUSTAKA}

Abraham Maslow. 'motivation and personality. 1943.

Achmad Rifa ${ }^{\mathrm{ee} I}$ dan Catharina Tri Anni. Psikologi Pendidikan. Semarang: UPT UNNES Press, 2011.

Ade Yuliasari dan Nanang Indriarsa. Peran Dominan Motivasi Instrinsik dan Motivasi Ekstrinsik Siswa Putri Dalam Mengikuti Kegiatan Ekstrakurikuler Futsal. Skripsi: UNS Surabaya, 2013. 
Amal. Ekstrakurikuler sekolah. 2005. http://www.repository.upi.edu/ ekstra kurikulersekolah. (7 Januari 2013).

Anifral Hendri. Ekskul olahraga membangun karakter siswa. 2008. http://repository.upi.edu/ekstrakur ikuler. (17 Januari 2013)

Ario Wiratmoko. Pengaruh Kegiatan Ekstrakurikuler Robotika Terhadap Kecerdasan Emosional Siswa di SMK Negeri 3 Yogyakarta. Skripsi: UNY Yogyakarta, 2012.

Dedy Sumiyarso. Keterampilan Bola Voli. Yogyakarta: Fakultas Ilmu Keolahragaan Universitas Negeri Yogyakarta, 2002.

Departemen Pendidikan dan Kebudayaan. Ekstrakurikuler. Jakarta: Balai Pustaka, 1995.

H.J.S Husdarta. Psikologi Olahraga. Bandung: Alfabeta, 2010.

Hamdan. Hubungan antara Kepercayaan Diri dengan Motivasi Berprestasi pada Siswa SMUN 1 Setu Bekasi. Skripsi: Universitas Gunadarma, 2009.

Masri Singarimbun dan Sofian Effendi. Metode Penelitian Survei. Yogyakarta: Lembaga Penelitian Pendidikan dan Penerangan Ekonomi Sosial, 1989.

Sardiman A.M. Interaksi dan Motivasi Belajar Mengajar. Raja Grafindo Persada, 2006.

Sekolah Punaji Setyosari. Metode Penelitian Pendidikan dan Pengembangan. Jakarta: Prenada Media Group, 2010.

Sodikun, Imam. Olah Raga Pilihan Bola Voli. 1992. Depdikbud:
Dirjendikti. Proyek Pembina Tebaga Kependidikan. Departemen Pendidikan Nasional 2004.

Sugiyono. Statistik untuk penelitian. Alfabeta, 2006.

- Metode penelitian pendidikan. Alfabeta, 2010.

- Metode Penelitian Kuantitatif, Kualitatif, dan $R \& D$. Bandung: Alfabeta, 2010.

Suharsimi Arikunto. Prosedur Penelitian Suatu Pendekatan Praktik. Jakarta. Rineka Cipta, 2006.

Sukandarrumidi. Metodologi Penelitian. Yogyakarta: Gadjah Mada University Press, 2006.

Syaiful Bahri Djamarah. Psikologi Belajar. Rineka Cipta, 2008.

Undang Undang Sistem Keolahragaan Nasional. 2005. http://www. google.co.id/ undang undang sistem keolahragaan nasional. (17 Januari 2013). 